\title{
Political Space Competition between Online and Conventional Transportation in Jakarta, Indonesia
}

\author{
Yusa Djuyandi ${ }^{1}$, Arief Hidayat ${ }^{2}$, Jumroh ${ }^{3}$ \\ ${ }_{1}^{1}$ Department of Political Science, Universitas Padjadjaran, Bandung, Indonesia \\ 2Departement of Politics and Government, Universitas Gadjah Mada, Yogyakarta, Indonesia \\ ${ }^{3}$ Faculty of Administration, University of Sjakhyakirti, Palembang, Indonesia \\ yusa.djuyandi@unpad.ac.id
}

\begin{abstract}
The Presence of online transportation brings a new problem in Indonesia transportation market competition, many conventional transportation drivers, such as taxis, buses, motorcycle taxis, city transportation (Angkot) that reject the presence of online-based transportation. For conventional transportation drivers, the existence of online transportation has reduced their income because people prefer to use online transportation rather than conventional transportation. As the power holder, the government certainly has the right and authority to regulate and create policy harmonization for public transportation. This study uses qualitative method where primary data is obtained from 8 months observations, from November 2017 to June 2018. Secondary data are obtained from transportation ministerial regulations, regional regulations issued by the DKI Jakarta Provincial Government, and various discourses that developed in the media mass. Various data obtained are then sorted or filtered and crosschecked against other data. Based on our findings, the government has not been arranged adequate political space, especially for conventional transportation and online transportation in Jakarta. The slow pace of the central government to revise regulations regarding online transportation has triggered serious conflicts in the community. Digital revolution in the dimensions of online transportation in the public interest is what should be an integral part of previous government policies, and that never happened.
\end{abstract}

Keywords: Transportation, Online, Government, Policy, and Political Space.

\section{Introduction}

Globalization era is an era where the world was getting close between individuals, groups or countries and make connections easily and quickly. Globalization makes freedom in opening a business so that anyone can open it in any form, anywhere. Usually, with globalization, people have owned businesses in several countries, namely by making investment and expansion markets. Freedom in opening a business began to be opened with the approval of the government and also the people welcome it with pleasure. Seeing the commitment of each country about economic growth, the government itself usually come to improve all aspects to get investment from businesses and from other governments. Today's world economy moves very dynamically, with globalization as its driving force. Slowly but surely, globalization has become a key driver for the emergence of world economic integration. Through globalization can be done an increase in investment, either directly and indirectl, encourage economic growth and employment. Paying attention to competition between increasing imperfect and competition business people, the values of fair business competition need to receive greater attention in the Indonesian economic system. Implementation of competition law is an economic instrument that is often used to make sure that competition between business people takes place in a healthy way and the results can be measured in the form of increasing public safety (Safitri, 2015).

Presence of transportation-based online application brings its own problems in the struggle for market space in the history of transportation in Indonesia. Problems that arise regarding the habits and preferences of the people who use transportation services are forced to move towards modern systems. In addition to conventional transportation, there is a problem of reduced income and less space due to changes in consumer patterns in choosing the type of transportation that will be used. Some big cities are indeed affected by changes in consumer patterns such as Jakarta, Surabaya, Medan, Yogyakarta, Semarang, Makassar, Bandung, etc. The next problem that arises is how does the concept of political space fight along with the growth of types of online transportation in big cities, especially in Jakarta. Jakarta as the National Capital of the Republic of Indonesia certainly has its own characteristics, especially in concerning the issue of public transportation and traffic jam. As a metropolitan city, the level of problem risk in Jakarta is related to traffic jam and transportation needs being a very interesting issue. For example, candidates for regional heads who are 
contesting in Jakarta, in addition to other crucial issues such as floods, fires, poverty, urbanization, garbage, etc.

The results of INRIX's research or analysis of traffic jam data from Washington, United States, released in 2017, explained that in 2016 car drivers in Jakarta spent 55 hours a year due to traffic jams. The data puts Jakarta at number 22 in the world's busiest city. The survey results also show that Jakarta traffic jam is "only" better than Bangkok, Thailand, which ranks first as the busiest city in Southeast Asia with a total time of 64.1 hours a year. DKI Jakarta is a business centre and government centre with a population in 2014 reaching 10.08 million people and a population density of 15,234 people per $\mathrm{km} 2$, surrounded by growing residential areas of Bogor, Depok, Tangerang and Bekasi (Bodetabek). From the results of the surreal Jabodetabek commuter in 2014 showed that the number of Jabodetabek commuters was 3,566,178 people, consisting of $2,429,751$ people doing work activities, schools and courses in DKI Jakarta, 1,067,762 people in Bodetabek and 68,665 people outside Bodetabek. While the commuter Bodetabek which carried out activities in DKI Jakarta was 1,382,296 people. This condition shows that massive transportation is an urgent need because the development of a good transportation sector will contribute significantly to developments in other sectors such as trade, industry, finance and services.Specific issues regarding transportation issues are also important, considering that transport service users have increased from year to year.

Management fair and decent concept of space is certainly a top priority compared to the others. That is why it seems the political space provided by the Provincial Government of Jakarta has become a very important aspect, in order to give an idea not only for practical spatial planning but also to be held in a policy. A good pattern of political space management will provide certainty about the designation and also clearer benefits for the community in general, business people and the government itself. The failure of the government in responding to the emergence of the issue of space politics can be seen with the horizontal conflicts in the fight of Gojek and Blue Bird's online market transport in Jakarta. As one of the business entities in the transportation sector, certainly strict and easy controls are needed. All of that was present because of the decisions in the country. But in this case, the state seemed to stutter and let the problems exploded and triggered wider conflicts. The government's failure to provide clear definitions and giddy government positions made the conflict more open. Indeed, it is not easy to manage the types of transportation in big cities like Jakarta. Although what needs to be looked at is how the government organizes political space through its policy instruments, and how does the instrument effectively work at the birth of the digital revolution era which causes disruption of technology?

Disruption of information technology has brought extraordinary changes. Things have emerged as the antithesis of conventional products and procedures of life. Indeed, there are many conveniences as well as benefits from the disruption of this technology. The impact of disruption is one of them is the emergence of online-based transportation or using applications. This type of transportation seems to deconstruct the concept of space (the term of public transportation is a route). Online transportation does not know the route and walks just like that according to consumer needs. Related to regarding regulation and also socio-political issues then encouraged the government to reaffirm the division of space through its authority. As the holder of power over space and policy, the government certainly has the right and authority to regulate and even force, so that it can create order and harmonization specifically related to public transport in Jakarta. The question that was tried to answer from this condition was:

- How does the government organize political space especially for conventional transportation and online transportation in Jakarta?

- To what extent is political space policy initiated and enforced by the government for online and conventional transport?

\section{Literature Review}

A. Public Space and Political Space: Space is a place where everyone conducts activities, individual and social activities. Space is very important for people's lives because of social, economic and political interactions. Space becomes one of the expensive commodities because the amount of space is limited and people want to get it more and more. The struggle for space is increasingly evident especially that space is a place where many people depend on their lives. Public space is often a struggle by many parties, by being able 
to get power over public space a person will get a large and dominant influence. In the context of political space, there are many things that must be fulfilled, especially related to the implementation and position of the government in providing certainty in the form of policy. The concept of political space itself is actually in contact with public space, which makes the public a top of priority in building relationships and networking within community entities (Huning, 2008).

The concept of political space is transformed into a more specific definition, namely space that is "public" and space that is "private"(Low \& Smith, 2006). In this concept of space since the days of ancient Greece (8-9 BC), where it was mentioned about the origin of a democratic state, there is the term "Oikos" which means house. The definition of reduction means a group of people who own a house. Form a unit and fulfil daily needs. People who join the Oikos will accept the consequences tied to the social rules that are formed. While the second, community groups that do not have property (Theses). Theses have an existence as a free person (Wibowo, 2010). The distinction has provided an illustration of the existence of "public" space and "private" space, and of course, in providing such definitions, it is still necessary to intervene with authority from the state. This concept will open an affirmation of the authority of the government in managing public spaces in defining the public interest. The existence of human which requires ease and hedonism (seeking pleasure and ease) also causes rational selection of various problems. Similar opinion was also conveyed by Thomas Hobbes who stated that humans are war creatures, which means that human beings always compete both healthily and not to get something they want, whether in the form of material or power.

From a clear separation of the private and the public, at least there are different approaches in the management of space as political entities rather than sociologically, because sociological entities lead to the dynamic aspects of human interaction in society as social beings, whereas political aspects are based more on the desire to master and conquer. In the concept of political space,all (practices) of modern countries divide their territory into complex and overlapping political and economic zones, reorganize the population and resources in units, and make the rules of how and by whom the area can be utilized space (Vandergeest \& Peluso, 1995). Therefore, the state pursues a territorial strategy as an effort to control the lives of the population through surveys and land registration, map making, establishment and supervision of forest areas and other natural resources. The strategy itself places a modern cartography technique as the main instrument of how the regulation and restrictions are carried out. If we connect between the concept of spatial planning and transportation problems in Jakarta, it will be very clear that government policy is still based on geographic political data which generally overlaps, as is the case with regulations regarding private forest management rights that clash with tradition/customary forests.

In addition, there are also opinions from Lefebvre where his views place space as a social product (Lefebvre, 1991). An understanding of this kind of space is indeed quite different, or totally different, compared to the old understanding of space. If in conventional understanding, space is always considered and imagined as an independent or self-contained material reality (space in itself). On the contrary, according to Lefebvre, space production is always tied to the social reality that surrounds it. Space has never been able to hold "itself" or manifest naturally. This understanding of the production of space does not have consequences; in other words, that space is "political," often as a means of thinking and acting. Space is able to direct people to think and act in their daily lives because it is meant to control and dominate. Space is not a sterile and neutral "box", but on the contrary, always something that is not simple and is always closely related to the issue of "power." Then, political space is a sign that will tell about a person's status hierarchy. Where, someone who can master space will get a lot of resources, such as economic and social resources Lefebvre, (1991) emphasized that various differences in the phenomenon of upper-class struggle in space are related to an area, region, site, land, etc.

This must be understood as part of the same spatial process. Basically, the spatial process is a combination of three elements. First, spatial practices related to individual routines for the systematic creation of zones and regions. Spatial planning practices over time are manifested in structured environments and landscapes. The most significant spatial practices in urban areas are related to the development of the property sector and other forms of operational capital. Second, having a representation of space, forms of knowledge, and practices that regulate and represent space, especially through planning techniques and the involvement of the state (government) third having collective space experience. This is related to the space of representation 
experienced by everyone. In this context, the market builds a system for the creation and accumulation of profits. Starting from Lefebvre's perspective, the real space has many types, but in this case the space is more focused on space that has many resources and economic potential.

B. Market: According to Stanton (2000: 92), markets are people who have the desire to be satisfied, money to shop and the willingness to spend it. From the definition above there are 3 important elements in the market, namely people with all their desires, their purchasing power and willingness to spend it. Market or consumers can be divided into two groups; the final consumer (consumer markets) and business markets (industrial market). Where a consumer market is a group of buyers, who buy goods for consumption rather than for further processing while the business market is a market consisting of individuals or organizations that buy goods to be processed again into other goods and then sold. Market is a place where there an interaction between sellers and buyers are both aimed at meeting their interests. In this case, the seller will get money and the buyer will adapt the desired goods or services. In the context of market policy, it is interpreted as an inseparable part besides the government and the public.

The market dimension becomes an entity that grows as separate from the government that is engagement between consumers and producers or providers of goods and services. Market concept is often known as the theory of demand theory describes the nature of the buyer in demand for an item, while the supply theory explains the nature of the seller in the supply of an item. Demand theory that explains the nature of the relationship between the amount of demand for goods and the price known as the law of demand. Where the higher the price of an item, the less the amount of goods to be requested and vice versa the lower the price of an item, the more quantity of goods requested. Bidding theory explains the nature of the relationship between the amount of goods offered and the price known as the law of supply, where the higher the price of an item, the better offered by the seller, and conversely the lower the price of an item, the fewer items offered. By connecting the buyer's request and the seller's offer, the market price and the amount of goods sold can be determined. Therefore, what happens in the market is an interaction that is not bound by policy values, because it is formed from the existence and supply or laws of demand and supply in the economy. The availability of online cases and conventional transportation is inseparable from the dynamics of the market formed between consumers who need transportation facilities that are easy, comfortable, and affordable.

On the one hand, Gojek application providers who are supposed to be able to fulfil the requested market in the competition between online and conventional transportation is a place where people need transportation services such as stations, terminals, airports, markets, and crowded places. In the market concept between conventional online transportation and transportation compete with each other to get consumers. In the economic world, it is also known as marketing concepts. According to Stanton (2000: 92), marketing is the whole system of business activities aimed at planning, pricing, promoting and distributing goods and services that can satisfy the needs of buyers and potential buyers. The core marketing concepts include needs, desires, demand, production, utility, value and satisfaction; exchange, market, marketing and market transactions and relationships. We can distinguish between needs, wants and requests. The need is felt the absence of a state certain basic satisfaction. Desire is a strong factor for the satisfaction that is specific to the needs of more profound needs. Meanwhile, demand is the desire for a specific product that is supported by the ability to buy it. Online public transportation and conventional public transportation compete to get as many consumers as possible by using marketing concepts, especially those related to price, service, and convenience. Consumer satisfaction is the most important. So, in every business activity, there is a principle that is "the customer is a king".

C. Policy: According to Carl Friedrich (in Indiahono, 2009: 18) policy is a direction that is followed by someone, group or government in a particular environment that provides some obstacles and opportunities for policies proposed to use and overcome in order to achieve a goal or realize a goal or a certain purpose. On the other hand, Anderson cited from (Winarno 2012: 201) policies have implications including: First, the focus of attention in public policy is oriented to purpose, not to haphazard behavior. Extensively public policy in the modern political system is not something that just happens but is planned by someone involved in the political system. Second, public policy is a direction for patterns or actions by government official is not a separate decision. A policy does not only include a decision to define laws regarding a matter but also the decisions and implementation. Third, the policy is about the government actually does in regulating trade, 
controlling inflation or promoting public housing, it does not for what the government wants. Fourth, public policy may be in the form of positive and negative.

Positively, policies may include clear forms of government action to influence a particular problem. Carl J. Federick as quoted by Agustino (2008: 7) defines policy as a series of actions or activities that suggested by a person, group, or government in a particular environment; there are obstacles (difficulties) and opportunities for implementing policy proposals in order to achieve the certain goals. This opinion shows that policy ideas involve behaviors that have an intention and purpose; this intention and purpose are an important part of the policy definition. However, policies must show what is actually done rather than what is proposed in some activities on a problem. The term policy itself was still a difference of opinion and was debated by experts (Wahab 2008: 40). Therefore, to understand the term policy (Wahab, 2008: 40-50) provides several guidelines as follows:

a. Policies must be distinguished from decisions;

b. Policies actually cannot be distinguished from administration;

c. Policies include behavior and expectations;

d. Policies include the presence or absence of action;

e. Policies usually have the final results to be achieved;

f. Each policy has a specific goal, either explicitly or implicitly;

g. Policy arises from a process that takes place over time;

h. Policies include inter-organizational relationships and intra-organizational ones;

i. Public policy, although not exclusive, concerns the key role of government institutions; and

j. The policy is formulated or defined subjectively.

\section{Method}

This study uses the qualitative method, because of using this method the research is able to see deeper the phenomena of space political competition between online and conventional transportation in DKI Jakarta. During the research process, the data obtained into to categorizes primary and secondary data. Primary data obtained for eight months observations, from November 2017 to June 2018. In addition, this study also obtained some secondary data, such as transportation ministerial regulations, regional regulations issued by the DKI Jakarta provincial government, and various discourses that developed in the media mass. Various data obtained are then sorted or filtered and crosschecked against other data. The purpose of conducting screening and crosschecking data is to create objectivity. Crosscheck data is a part of the data triangulation process, where appropriate or conflicting data is then carefully viewed and analyzed.

\section{Discussion}

Gojek is a start-up company it has just appeared in Indonesia. Gojek's company development is very significant, where the drivers have reached tens of thousands of drivers, and they made their own community. The emergence of Gojek is the answer to the badness of transportation services in Indonesia. It is the service transportation preferred by a citizen, because the cost is cheaper, the service and comfort are more satisfying. Especially this company has an online application; it makes the drivers can pick up the customer directly. Gojek also has many features and services such as sending goods (GO-SEND), Motorbike Transportation (GO-RIDE), Ordering food (GO-FOOD), Shopping (GO-MART), Large goods (GO-BOX), cleaning houses (GO-CLEAN), Beauty (GO-GLAM), Massage or reflection (GO MASSAGE), Transjakarta Schedule, delivery from the nearest stop or to the nearest stop (GO-BUSWAY), Book a ticket (GO-TIX), Car Transport (GO -CAR), Mechanics (GO-AUTO), Health Medicines (GO-MED), Credit (GO-PULSA), Goods Shopping (GOSHOP), and Blue Bird Taxi (GO-BLUEBIRD).

A. The Arrangement of Online and Conventional Public Transportation in Jakarta: In December 2015, Ignasius Jonan as the Minister of Transportation released an operational ban on motorized vehicles not for public transportation based on online applications, because these companies were not eligible the regulations on public transport. The prohibition is in the notification letter Number UM.3012 / 1/21 / Phb / 2015 signed by the Minister of Transportation on November 9, 2015. It did not last until 24 hours the ban was revoked 
after an intervention from President Joko Widodo. Only a few months later, exactly on March 22, 2016, a number of conventional taxi drivers marched on the streets in Jakarta to demand the prohibition of operating public-based online transportation. Even worse, there is a dispute between conventional taxi drivers and online-based transportation drivers. Based on the existing rules, online transportation was not eligible for the provisions as transportation, as stipulated in Law Number 22 of 2009 concerning Road Traffic and Transportation. The other rules exist in Government Regulation Number 74 of 2014 concerning Road Transportation. Although it was not in accordance with regulations, the phenomenon of online transportation continues to flourish in urban areas.

The dynamics and inexperience of the government in understanding the changing patterns of using public transportation in Jakarta, based on the government's interference about the regulations, do not provide a solution but instead, the government includes being a part of the problem. The Ministry of transportation considers that online transportation in regulation was not eligible with the requirements, but in the policy of the President as the highest executive power in the government acts otherwise. The socio-political impact that arises in this confusing area, at least the community understands that: First, the government is not ready for the changes that occur. Second, society wants comfortable, cheap and safe transportation. Third, technology disruption through online applications can bring new patterns in the habit of using public transportation. Fourth, the potential for conflicts that occur in the community due to government uncertainty the online application that has just emerged, is becoming a new competitor in the field of transportation, of course, it has a surprising effect on businessmen and conventional drivers. The government has actually seen this shift, but it is still uncertain given that public transportation still refers to old regulations and has not been modified or adapted to more modern needs.

Figure 1: Successful Startup infoGraphics in Indonesia 2016, Communication and Information Version

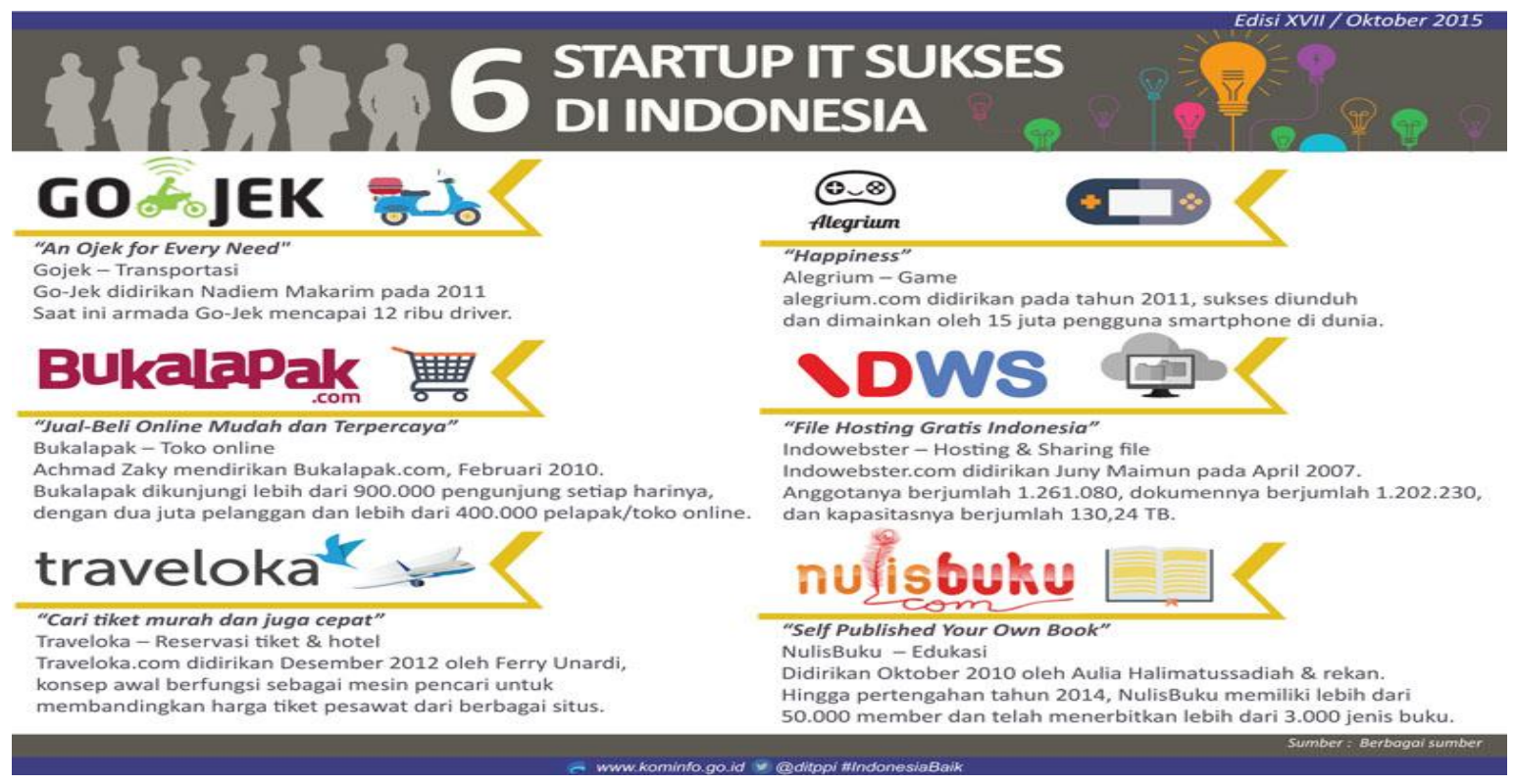

rce: Communication and Information, 2016.

By looking, at this current development, especially with the contextualization of Jakarta as the capital city of the country capable of having a wide impact on other regions the emergence of online transportation initiated by Gojek as the first online transportation is the most creative breakthrough in the 2016 communication and communication version in the field of startup (Figure 1). In addition, there are changes that occur because consumers who prefer practicality, besides that, this is also the effect of information technology disruptions that are increasingly massive and unavoidable. In addition to the benefits in the hands of consumers, as a first step, Gojek is able to provide new jobs with more than 12 thousand partnership vacancies in just 4 years. 
Figure 2: Info Graphics of Online Motorcycle Taxis vs. Conventional Motorcycle Taxis

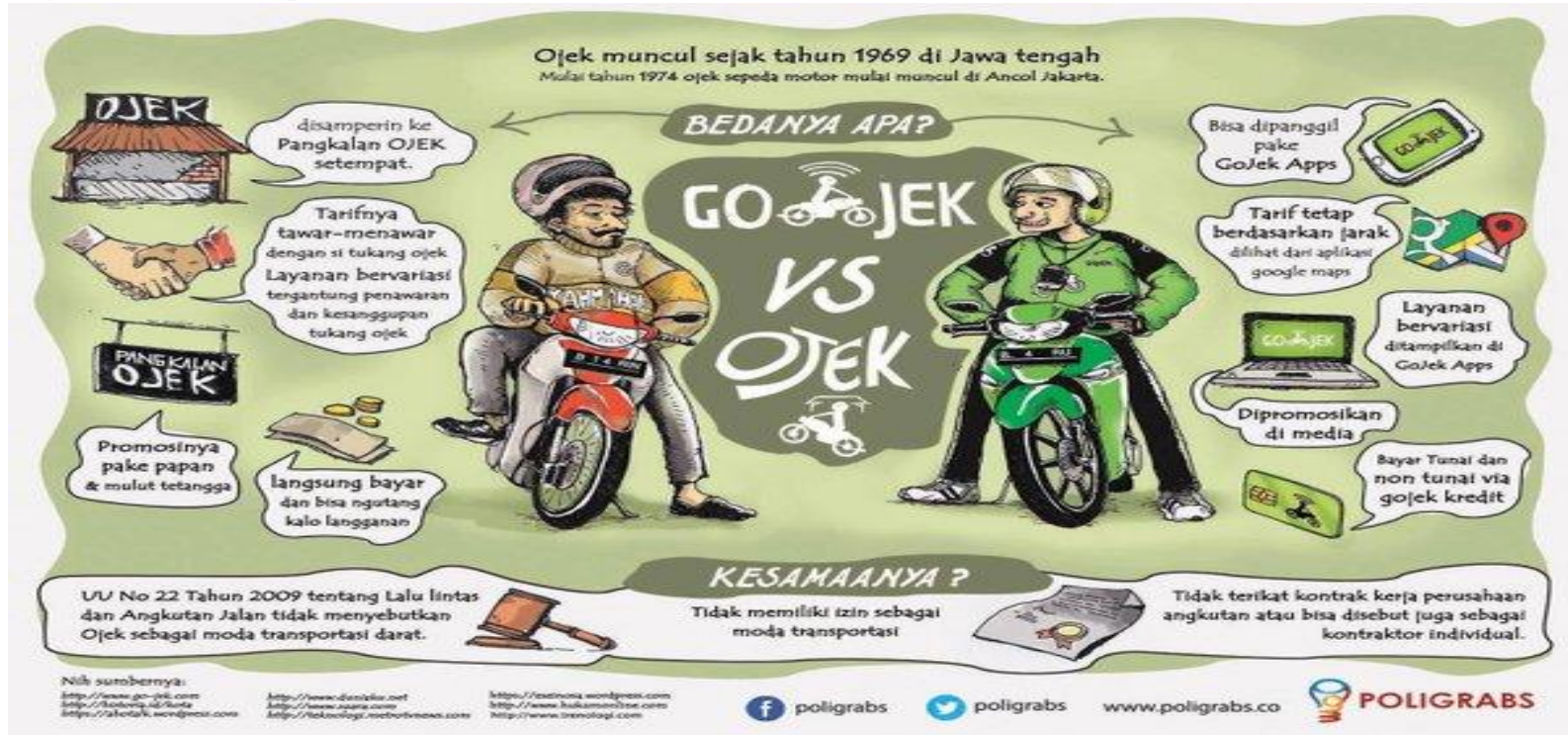

Source: www.Poligrabs.co

Talking about modern life at this time, transportation services are a tool that is needed by society in generals. Community needs for transportation services, encourage many companies to open transportation businesses. Transportation services are increasingly innovating, especially since the development of technology, where online-based transportation has begun to be in great demand by the public. The development of online-based transportation makes them always have to serve consumers wherever they are, so online transportation often operates in places where many people need it. The development of online transportation that is increasingly rapid and much in demand by the public makes transportation that is not based online or conventional to feel marginalized, resulting in problems between online and conventional transportation. Space struggles in the analysis of problems regarding online and conventional transportation between Gocar taxis and Bluebird taxis, for example, where they are trying to get the most strategic space, especially space where people need transportation services such as terminals, stations airports and so on. The politics of space that occur in Jakarta is very clear the motive is to get the potential of economic resources. The existence of online transportation is increasingly being regarded as a serious threat by conventional transportation service providers.

This caused a prolonged conflict between the two parties, both initially only a mouth-to-mouth argument, so as to use violence. This is what makes the government have to intervene by giving regulations regarding the existence of online transportation. Given the government's failure to respond to online transportation during Ignasius Jonan's time, the government learned to understand and try to adjust needs regarding the rules of online transportation. Then technical regulations are adjusted to answer this challenge. At least there are several important points outlined by the government as a middle way so that the existence of online transportation is able to continue to exist because it has become part of the public interest. To overcome this online transportation chaos, the government has adopted a policy to issue Ministerial Regulation (MR) No. 108 of 2017 concerning the Implementation of Public Transportation with Public Motor Vehicles Not on Route. This Minister of Transportation Regulation is a substitute for MR Number 26 of 2017. The Minister of Transportation Regulation Number 108 will be active on November 1, 2017, as an answer to anxiety between online transportation and conventional transportation. Here are nine new rules in the Minister of Transportation Regulation No. 108/2017:

- Taxi taximeter: the amount of tariff according to what is stated on the meter.

- Tariff: tariff determination is based on the agreement of service users and transportation service providers. The guideline is the upper and lower tariffs set by the Director General of Land Transportation at the proposal of the Head of BPTJ or the Governor in accordance with his authority. 
- Area of operation: operates in the area of operation that has been determined by the Director General of Land Transportation or the Head of BPTJ or Governor.

- Quota: the quota for vehicle needs is determined by the Director General of Land Transportation or the Head of BPTJ or Governor.

- Number of vehicles: a minimum of five vehicles. For individuals who have less than five vehicles, they can gather in legal entities in the form of cooperatives that already have permission to operate online taxis.

- Proof of motor vehicle ownership: BPKB (Motor Vehicle Ownership Proof) or STNK (Vehicle Number Certificate) on behalf of legal entities / on behalf of individual legal entities in the form of cooperatives.

- Domicile of motorized vehicle number (TNKB): online taxi using TNKB according to the designated operating area.

- Type Test Registration Certificate (TTRC): requirements for permit applications for new motorized vehicles must attach a copy of the TTRC of a motorized vehicle.

- Role of applicator: application companies in the field of transportation are prohibited from acting as organizers of public transport.

The issuance of this regulation is expected to provide certainty about the government's position regarding online transportation. Indeed, this regulation has long been issued as a solution, but the government's delay in issuing it has caused a prolonged conflict. Besides that, seeing from the authority they have, it turns out that the arrangement regarding public vehicles is not owned by the provincial government. The DKI Jakarta Provincial Government is only authorized to issue policies on routes, the number of tariffs, the number of transportations, the type of transportation, and does not have the issuance of authorization permits relating to the type of transportation and other permits. So, if indeed there is chaos regarding online transportation that occurs in various regions, fully it is indeed the responsibility of the central government. This policy is actually awaited as a quick response. In addition, the government is also needed to be able to provide mediation regarding conflicts that occur.

For example, the government must dare to take a clear line so that the conflicting parties reach a level of compromise because if the conflict extends not only entrepreneurs will be in trouble, but also the wider community. The government has not been able to resist the presence of information technology disruptions because it has become a daily necessity of the community. What needs to be done by the government is to provide facilitation and clarity of standing position on this issue. That means, in the use of online applications in public transport vehicles it cannot be avoided as a consequence of the presence of a digital revolution in public space. In addition, the government must also realize that although existing regulations are inadequate, the market as a separate entity will form its own ecosystem through the legal chain of supply and demand. This is inevitable given the market mechanism as separated from the state. The state is only present to provide protection for protected areas of public interest, related to risks if in the future there are parties who violate their rights and feel disadvantaged. The presence of a market mechanism proved effective even though previously the government had not issued a revised regulation of the Minister of Transportation Regulation No. 108 of 2017 concerning the Implementation of People Transportation with General Motor Vehicles Not on the Route.

B. Political Policy of Online and Conventional Space in Jakarta: In the context of space politics, the DKI Jakarta government has actually rolled out technical rules regarding routes and specifications of the types of transportation that pass certain routes. If we return to the concept of space presented by Vandergeest \& Peluso (1995) the context is segmentation and mapping of space and region based on geographical elements. In fact, the government cannot reach this spatial planning source for transportation. Spatial planning is not intended for the dimensions of public transport, but only for land use areas. According to this condition, the concept of space has diminished considerably, even though in a fight over spatial, each area or space within the government is then filled with community activities. The government's duty is to ensure that aspects of the public space do not overlap interests and also provide certainty for the government's standing position. 
If the government reduces the role of political space, of course, this concept is very far away from fact. It seems that the DKI Jakarta Provincial Government is also experiencing the same thing. The complexity of the problems associated with this space does not reach the place and how spatial planning for transportation in particular. The DKI Jakarta government only focuses on transportation modes and tariffs but does not mention at all the fair distribution of space. Although the concept of spatial planning is unavoidable if the economic activities of citizens run even though the qibla is an invisible hand through the law of demand and supply in the economic field, the political impact of weak spatial planning makes transport war between providers as difficult to prevent. The market cannot be separated from government interference.

\section{Conclusion}

From the description described earlier, several conclusions can be drawn including:

A. in the event that the government regulates the politics of space, especially for conventional transportation and transportation online in Jakarta, has not yet been completed. The existing spatial aspects are reduced in the context of land use mapping and do not touch on the transportation aspect. Although the real dimensions of the relationships contained in public transport activities are important elements in the spatial aspect. In addition, the DKI Jakarta government authorities do not have the authority to regulate transportation problems because the authority is in the central government through the Ministry of Transportation.

B. The political policy of space initiated and implemented by the government for online and conventional transportation does not fully accommodate the interests of the community. The slow pace of the central government to revise regulations regarding online transportation has triggered serious conflicts in the community. In addition, the government has not fully realized that the public enjoys information technology disruption which has led to the ease of use of online transportation facilities. In addition, it is inevitable that people will switch to online transportation because they enjoy the benefits that are also different from conventional transportation and also the modes of transportation provided by the government. Digital revolution in the dimension of online transfortasi for the public interest is what should be an integral part of previous government policies, and that never happened.

Suggestions: From the conclusions, there are at least a number of suggestions that can be proposed for increasing online transportation arrangements in Jakarta in particular, with the following details:

A. The dynamics of online transportation is a must so that the government must be more open in this matter. DKI Jakarta as a Provincial Government or other regional government needs to be given more authority in regulating transportation and contributing to the political aspects of space to be clearer and more transparent.

B. The era of information technology disruption makes everything easy, inexpensive, comfortable and transparent. Economically, consumers get maximum satisfaction. However, from a political point of view, the market struggle carried out by giant transportation businessmen will become unhealthy, because it involves management so far or the concession rights they receive from the government are disrupted by those who have just entered the ecosystem with different concepts. The main step is that the government mediates and seeks a compromise so that all parties feel accommodated.

\section{References}

Agustino, L. (2008). Dasar- dasar Kebijakan Publik. Bandung: Alfabeta.

Huning, S. (2008). Political Activity in Public Spaces: Awakening, Stagnation, or Fall? In M. Nowak, \& M. Nowosielski, Declining Cities/Developing Cities: Polish and German Perspectives (pp. 190-201). Poznan: Instytut Zachodni.

Hutapea, E. (2017, September 6). Kompas.com.

Indiahono, D. (2009). Kebijakan Publik Berbasis Dinamic Analysis. Yogyakarta: Davamedia.

Lefebvre, H. (1991). The Production of Space. Oxford: Blackwell Publishers, Ltd. 


\section{Journal of Social and Development Sciences (ISSN 2221-1152)}

Vol. 10, No. 1, pp. 1-10, March 2019

Low, S. M. \& Smith, N. (2006). The Politics of Public Space. New York: Routledge.

Safitri, M. (2015). Tinjauan Hukum Persaingan Usaha Terhadap Konflik Antara Taksi Konvensional dan Taksi Online. Jurnal Keadilan Progresif, 6(2), 138-148.

Stanton, W. J. (2000). Prinsip Pemasaran. (Y. Lamarto, Trans.) Jakarta: Erlangga.

Vandergeest, P. \& Peluso, N. L. (1995). Territorialization and state power in Thailand. Theory and Society, $24(3), 385-426$.

Wahab, S. A. (2008). Analisis Kebijaksanaan; Dari Formulasi ke Implemen tasi Kebijaksanaan Negara. Jakarta: Bumi Aksara.

Wibowo, A. S. (2010). Kepublikan dan Keprivatan dalam Polis Yunani Kuno. In F. B. Hardiman, Ruang Publik: Melacak Partisipasi Demokratis dari Polis Sampai Cyberspace (p. 27). Yogyakarta: Kanisius.

Winarno, B. (2012). Kebijakan Publik (Teori, Proses dan Studi Kasus). Yogyakarta: Buku Seru. 